\title{
STUDI DAMPAK IMPLEMENTASI MOTTO KOTA SERANG DENGAN PENDEKATAN TEORI FENOMENOLOGI HUSSERL
}

\author{
Marthalena \\ Program Studi Administrasi Negara Universitas Serang Raya \\ Email: marthalena.marthalena@gmail.com
}

\begin{abstract}
Serang City has a symbol in which there is the Motto Serang Madani City. A word that becomes motivation from Serang city in running its government. The motto should be a mutual consensus between the people of Serang City and the city government of Serang. The motto that should have been the way of life of the people of Serang City. Implementation of the Serang City Motto is observed in depth with regard to the visible phenomenology. If the implementation is going well then it will seem the impact in daily life of the people of Serang city associated with the Motto. In his writing, Motto's implementation is reviewed in the areas of hygiene, orderliness, arrangement of street vendors, parking, terminal arrangement and public transportation. The result of this research is to see the various phenomenon that appear in the field can be concluded that the motto of Serang Madani City is not implemented in the middle of life of Serang city because of the low self awareness (self consiusnes) of Serang City to obey the regulations that have been made by the government of Serang City
\end{abstract}

Keywords: Implementation, Motto, phenomenology

\section{PENDAHULUAN}

Kota Serang adalah salah satu dari delapan Kabupaten/Kota yang ada di Provinsi Banten yang mempunyai kedudukan sebagai pusat Pemerintahan Provinsi Banten. Kota Serang merupakan wilayah baru hasil pemekaran dari Kabupaten Serang dengan di tandatanginnya UU Nomor 32 tahun 2007 tentang pembentukan Kota Serang di Provinsi Banten pada tanggal 10 Agustus 2007.

Kota Serang memiliki 6 kecamatan dan 66 kelurahan. Penduduk Kota Serang berjumlah 613.774 jiwa dengan kepadatan penduduk $2.301 \mathrm{jiwa} / \mathrm{km} 2$. Mayoritas Penduduk Kota Serang beragama Islam dengan suku bangsa Jawa Banten. Saat ini Pemerintahan Kota Serang di pimpin oleh Tb Haerul Jaman sebagai Walikota dan Sulhi Choir sebagai Wakil Walikota. APBD Kota Serang berkisar di Rp 1.02 Trilyun per Tahun.

Kota Serang juga dikenal sebagai Kota Santri, yang identik dengan filsafat kehidupan Pesantren. Yang terkenal dengan kereligiusannya. Hari-hari besar Islam di kota Serang selalu ramai dan di meriahkan dengan acara pawai dan sebagainya. Melibatkan setiap komponen lapisan masyarakat. Sebagai contoh acara Maulid Nabi, hampir di setiap kampung, musholla ataupun masjid mengadakan panjang mulud yang salah satu rangkaian acaranya adalah pawai bersama.

Kota Serang memiliki Visi atau Motto

Kota Serang Madani. Motto tersebut termaktub dalam Lambang Kota Serang yang memiliki makna sebuah cita-cita untuk menjadikan Kota Serang yang memiliki ciri sebagaimana masyarakat Madinah yang pernah terwujud nyata pada masa Nabi Muhammad SAW. Yaitu kota yang baldhatun thoyibathun warobbun ghofur sehingga menjadi kota dan masyarakat yang maju, adil, damai, sejahtera dan modern. Dalam konteks historis, karakter madani pernah terbangun di era Kesultanan Islam Banten yang berpusat di kawasan Banten Lama, sehingga cita-cita ini menemukan keterkaitan dengan jejak sejarah Kota Serang dimasa lalu. 
Dalam penjelasan makna Lambang Kota Serang pada web resmi DPRD Kota Serang (dprd-serangkota.go.id), Motto Madani memiliki makna sebagai berikut :

1. Menghormati kebebasan beragama

2. Menjaga persaudaraan antar umat beragama

3. Menjaga perdamaian dan kedamaian

4. Menjaga persatuan

5. Etika Politik yang bebas dan bertanggung jawab

6. Pemerintah yang melindungi hak dan kewajiban masyarakat

7. Konsistensi penegakan hukum berdasarkan kebenaran dan keadilan

8. Terciptanya masyarakat yang demokratis

9. Menghormati hak-hak asasi individu

10. Selalu berada dalam koridor agama

Semua itu diharapkan dapat terwujud dalam pemerintahan Kota Serang yang bersih, adil, bertanggung jawab, agung dan berwibawa sehingga dapat menciptakan masyarakat kota Serang yang sejahtera disemua bidang (sosial, politik, budaya, dan pendidikan)

Motto Kota Serang Madani menjadi tema utama di setiap SKPD yang ada di Kota Serang. Mereka menjadikan Kota Serang Madani adalah sebuah Visi besar yang harus dapat diturunkan kepada setiap program kerja di masing-masing SKPD. Artinya, Motto tersebut tersosialisi dengan baik di kalangan pemerintah kota Serang, namun bagaimana dengan Implementasinya ditengah masyarakat kota Serang. Apakah motto tersebut benar dirasakan oleh masyarakat Kota Serang?

Dalam buku yang berjudul Policy Implentasi and Bureacracy, Randall B. Repley and Grace A Franklin (1986 : 232-33), (dalam Alfatih, 2010 : 51-52), menulis tentang three conception relating to succesful implementation :

The nation of success in implementation has no single widly accepted definition, diiferent analist and different actors have very different meaning in mind when they talk about or think about succeful implementation. There are three dominant ways of thinking about succeful implementation

Three dominant ways tersebut adalah tiga parameter yang dapat dijadikan sebagai ukuran keberhasilan sebuah kebijakan diimplementasikan. Adapun ketiga alat ukur tersebut adalah :

1. Tingkat kepatuhan pada ketentuan yang berlaku.

Perspektif ini memahami keberhasilan implementasi dalam arti sempit yakni sebagai kepatuhan para implementor dalam melaksanakan kebijakan yang tertuang dalam dokumen kebijakan (dalam hal ini Motto Kota Serang Madani)

2. Lancarnya pelaksanaan rutinitas fungsi.

Keberhasilan implementasi ditandai dengan lancarnya rutinitas fungsi dan tidak adanya masalah-masalah yang dihadapi

3. Terwujudnya kinerja dan dampak yang dikehendaki

Implementasi kebijakan dapat dikatakan berhasil bila mangacu atau mengarah pada dampak atau manfaat yang dikehendaki dari kebijakan tersebut

Tertarik dengan Motto Kota Serang Madani yang tertulis pada Lambang Kota Serang untuk dikaji keberhasilannya dengan melihat fenomena yang terjadi, dialami, dirasakan oleh penulis dengan mengunakan parameter ketiga hal tersebut diatas. Maka peneliti meneliti terkait dengan bagaimana implementasi kebijakan motto Kota Serang dengan menggunakan teori fenomenologi Husserl.

\section{FENOMENOLOGI HUSSERL}

Fenomenologi secara umum adalah studi mengenai sebuah kenyataan sebagaimana hadirnya, tampilnya. Sementara kata Fenomenologi sendiri berasal dari bahasa Yunani, phenomenon, yaitu sesuatu yang tampak, atau penampilan. Dalam bahasa Indonesia biasa di pakai istilah Gejala. Secara 
Istilah, fenomenologi adalah Ilmu pengetahuan (logos) tentang apa yang tampak. Dari pengertian tersebut dapat dipahami bahwa fenomenologi adalah suatu aliran yang membicarakan fenomena atau segala sesuatu yang tampak atau yang menampakkan diri. Meskipun kata tersebut sudah banyak digunakan oleh para pemikir sebelumnya, namun Husserl memiliki konsep sendiri dengan batasan yang lebih jelas dan tegas. Konsep fenomen menurut Husserl sebagai sesuatu (realitas kehidupan, obyek, realitas yang sifatnya nampak) sebagaimana yang kita alami dan menghadirkan diri dalam kesadaran kita (Lathief, 2010:30).

Seorang fenomenolog suka melihat gejala. Dia berbeda dengan seorang ahli ilmu positif yang mengumpulkan data, mencari korelasi dan fungsi, serta membuat hukumhukum dan teori. Fenomenolog bergerak di bidang yang pasti. Hal yang menampakkan dirinya dilukiskan tanpa meninggalkan bidang evidensi yang langsung. Fenomenologi adalah suatu metode pemikiran "a way of looking at things"

Dari keterangan di atas dapat dipahami bahwa fenomenologi ini mengacu kepada analisis kehidupan sehari-hari dari sudut pandang orang yang terlibat didalamnya. Tradisi ini memberi penekanan yang besar pada persepsi dan interpretasi orang mengenai pengalaman mereka sendiri terkait fenomena yang ada dilingkungan sekitarnya.

Bagi seorang fenomenolog, kisah seorang individu adalah lebih penting dan bermakna daripada hipotesis ataupun aksioma. Seorang penganut paham fenomenologi cenderung menentang segala sesuatu yang tidak dapat diamati. Fenomenologi juga cenderung menentang naturalisme (biasa juga disebut objektivisme atau positivisme). Hal demikian dikarenakan Fenomenologi cenderung yakin bahwa suatu bukti atau fakta dapat diperoleh tidak hanya dari dunia kultur dan natural, tetapi juga ideal, semisal angka, atau bahkan kesadaran hidup
Jelasnya fenomenologi mencoba menepis semua asumsi yang mengkontaminasi pengalaman konkret manusia. Ini mengapa fenomenologi disebuat sebagai cara berfilsafat yang radikal. Fenomenologi menekankan upaya menggapai "hal itu sendiri" lepas dari segala presuposisi.

Edmund Gustav Albrecht Husserl seorang filosof Jerman dan tokoh utama gerakan fenomenologi yang dilahirkan pada tanggal 8 April 1859 di Prostejov, Moravia, Ceko. Ia merupakan Filsuf Jerman yang dikenal sebagai bapak Fenomenologi. Karyanya meninggalkan orientasi yang murni positivis dalam sains dan filsafat pada masanya, dan mengutamakan pengalaman subyektif sebagai sumber dari semua pengetahuan kita tentang fenomena obyektif.

Menurut Husserl, Fenomena adalah realitas sendiri yang tampak, tidak ada selubung atau tirai yang memisahkan subyek dengan realitas, karena realitas itu sendiri yang tampak bagi subyek. Dengan pandangan seperti ini, Husserl mencoba mengadakan semacam revolusi dalam filsafat barat. Hal demikian dikarenakan sejak Descartes, kesadaran selalu dipahami sebagai kesadaran tertutup (cogito tertutup), artinya kesadaran mengenal diri sendiri dan hanya melalui jalan itu dapat mengenal realitas. Sebaliknya Husserl berpendapat bahwa kesadaran terarah pada realitas, dimana kesadaran bersifat "intensional", yakni realitas yang menampakkan diri.

Sebagai seorang ahli fenomenologi, Husserl mencoba menunjukkan bahwa dengan menggunakan metode fenomenologi mengenai pengalaman biasa menuju pengalaman murni, kita bisa mengetahui sebuah kepastian absolut dengan susunan penting aksi-aksi sadar kita, seperti berpikir dan mengingat, dan pada sisi lain susunan penting obyek-obyek merupakan tujuan aksiaksi tersebut.

Lebih jauh lagi Husserl berpendapat bahwa terdapat sebuah kebenaran untuk semua orang dan setiap manusia dapat mencapainya. Dan untuk menemukan 
kebenaran ini, seseorang harus kembali kepada "realitas" itu sendiri. Dalam bentuk slogan, Husserl menyatakan "Zuruck zu den sachen selbst" kembali kepada benda-benda itu sendiri, merupakan inti dari pendekatan yang dipakai untuk mendeskripsikan realitas menurut apa adanya.

Dengan menggunakan teori fenomenologi Husserl penulis menganalisis bagaimana implementasi motto Kota Serang dengan mengamati secara langsung realitas yang terjadi di tengah masyarakat kota Serang tanpa memisahkan subyek dengan realitas, karena realitas itu sendiri yang tampak bagi subyek.

\section{FENOMENOLOGI MASYARAKAT KOTA SERANG}

Penulis tinggal dan menetap di Kota Serang sejak bulan Agustus 2014. Sebelumnya penulis tinggal di Kota Bandar Lampung, Provinsi Lampung. Penulis tinggal dan menetap di tengah-tengah penduduk asli kota serang. Penulis hampir setiap hari Sabtu dan Minggu melakukan perjalanan menggunakan kendaraan roda dua untuk mengitari Kota Serang dan mengamati secara seksama Kota Serang.

Banyak hal yang penulis, amati, rasakan, alami dan sebagainya terkait dengan keseharian masyarakat kota Serang. Dalam tulisan ini, Penulis sengaja untuk menghubungkan dengan Moto Kota Serang yakni Kota Serang Madani atau implementasi Moto tersebut ke kehidupan sehari-hari masyarakat kota Serang.

Fokus pengamatan penulis adalah :

1. Kebersihan, Keindahan

2. Tata kelola Pedagangan Kaki Lima dan Parkir

3. Tata kelola angkutan umum (Angkot) dan Terminal

4. Lainnya (selain dari ketiga point diatas)

\subsection{Kebersihan dan Keindahan}

Kebersihan merupakan sebagian daripada Iman. Kalimat tersebut sudah memasyarakat terutama di Kota serang yang memiliki Moto Kota Serang Madani yang lebih identik dengan nuansa keislaman. Setiap warga Kota Serang dapat diyakinkan mengetahui kalimat tersebut. Dari anak-anak sampai orang tua, dari rakyat kecil hingga Walikota, semua orang paham arti dari kalimat tersebut.

Pemahaman tersebut sejalan dengan Moto Kota Serang Madani. Kota Madani merepresentasikan Kota Madinah di zaman Rasullah. Kota yang senantiasa menjunjung tinggi nilai-nilai keislaman, termasuk masalah kebersihan. Itu pula yang diharapkan tumbuh dan menjadi sebuah realita di tengah masyarakat kota Serang.

Namun realitas yang terjadi di tengah masyarakat Kota Serang justru Fenomena yang penulis dapati adalah sebagai berikut :

1. Masyarakat sering kali membuang sampah di sungai atau kali walaupun telah di tertulis "Jangan Buang Sampah di Sungai atau Kali"

2. Masyarakat membuang sampah di pinggir jalan yang tidak ada tanda tempat tersebut dijadikan TPS (Tempat Penampungan Sementara) ataupun Bak Sampah

3. Abai terhadap rambu "Dilarang Membuang Sampah Disini”

4. Budaya membuang sampah pada tempatnya belum menjadi sebuah trend setter. Sering kali didapati sampah plastik, sisa makanan dijalan-jalan protokol. Bahkan di depan Kantor Pemerintahan (Kantor Bupati Serang, Alun-alun kota Serang) sampah dengan mudah didapati bila diarea tersebut diadakan acara besar

5. Dengan mudahnya masyarakat Kota Serang memasang Spanduk, Baliho, Banner, Leaflet, atau alat peraga Kampanye Pilkada dengan tidak mempertimbangkan keindahan kota. 
6. Membuang sampah di tanah kosong di area permukiman dan membakarnya.

7. Drainase di pinggir jalan menjadi alternatif pembuangan sampah sehingga menjadi salah satu penyebab banjir dikala musim hujan

\subsection{Tata kelola Pedagangan Kaki Lima dan Parkir}

Kota Serang merupakan Ibu kota Provinsi Banten. Sudah sepatutnya permasalahan Pedagang kaki lima dan parkir menjadi tolak ukur atau teladan bagi daerah lainnya.

Namun fenomena yang ditemukan oleh peneliti adalah sebagai berikut :

1. Pedagang Kaki Lima sering menggunakan Badan Jalan untuk berdagang sehingga menggangu kelancaran berlalu lintas (timbul kemacetan)

2. Pedagang Kaki Lima berdagang di Trotoar Jalan sehin.gga menggangu pejalan kaki

3. Pedagang Kaki Lima berdagang di depan Ruko

4. Parkir kendaraan yang menggunakan badan jalan. Sehingga memperkecil ruas jalan yang dapat dilalui oleh kendaraan

5. Pertokoan, minimarket atau warung di pinggir jalan tidak menyediakan lahan parkir yang cukup untuk menampung kendaraan yang bertransaksi

6. Tidak ada antisipasi yang cukup solutif terhadap pengelolaan parkir disaat terdapat kegiatan besar di sekitaran Jalan Protokol yang membuat peserta kegiatan tersebut menggunakan badan jalan untuk parkir kendaraan

\subsection{Tata Kelola Angkutan Umum dan Terminal}

Angkutan Umum merupakan "Pembuluh darah" dari pergerakan orang dan jasa di sebuah daerah. Kejelasan, efisiensi, efektifitas merupakan sebuah keharusan dari sebuah sistem angkutan umum. Apatah lagi sebuah ibukota provinsi yang berbatasan dekat dengan pusat pemerintahan RI.

Namun pada kenyataannya, sistem angkutan umum yang di amati oleh penulis adalah sebagai berikut :

1. Tidak jelasnya rute dari sebuah angkutan kota. Darimana dan kemanakah tujuan dari angkutan tersebut. Rute yang tertulis di kaca angkutan kota tidak mencerminkan rute dari kendaraan tersebut

2. Tarif yang diberlakukan oleh angkutan umum (angkutan kota) sering menggunakan sistem "tembak". Tidak berdasarkan jarak tempuh pengguna angkutan kota.

3. Budaya "ngetem" yang senantiasa dipegang teguh oleh para angkutan kota membuat pengguna angkutan kota menjadi tidak efisien dan efektif

4. Budaya berhenti atau menurunkan penumpang di area larangan berhenti atau diperempatan jalan sering menjadi penyebab terjadi kemacetan panjang jalan protokol

5. Penumpang yang diturunkan sebelum sampai ditujuan merupakan hal yang biasa

Terkait dengan terminal, beberapa fenomena yang penulis dapatkan. Antara lain sebagai berikut :

1. Terminal yang tidak rapih, tidak bersih, tidak tertata dengan baik menjadi pemandangan umum

2. Angkutan Umum lebih senang untuk menurunkan penumpang di pintu masuk terminal bukan didalam terminal

3. Angkutan umum sering mencari penumpang atau "Ngetem" disekitaran pintu masuk terminal

4. Sampah berserakan, dengan mudah didapati sampah di sekitaran terminal

5. Tidak terawat merupakan kesan awal yang didapati saat memasuki terminal 


\section{Implementasi Motto Kota Serang Madani}

Sudah sepatutnya dan seharusnya, sebuah motto di cetuskan atau didengungkan untuk menjadi sebuah motivasi bagi seseorang ataupun kelompok untuk menjadi lebih baik lagi.

Sebuah Motto dikatakan telah terimplementasi dengan baik dapat dilihat dari dampak atau efek yang ditimbulkan dari motto tersebut. Motto bukan hanya menjadi slogan dan memperindah sebuah lambang kota atau menjadi sebuah simbol kebanggaan dari sebuah kota namun Motto tersebut harus menjadi motor penggerak agar hal-hal yang baik yang menjadi tujuan motto tersebut dapat terwujud.

Bila ditelaah lebih dalam terkait dengan fenomena yang penulis jabarkan maka terdapat beberapa hal penting yang menjadi perhatian, antara lain :

1. Rendahnya tingkat kedisiplinan dan ketertiban terkait kebersihan dan keindahan kota

2. Ketidakpatuhan terhadap peraturan yang berlaku

3. Rendahnya tingkat penegakan hukum atas peraturan yang dilanggar

4. Kurang inisiatif dan kreatif serta solutif dari pemerintah untuk memperbaiki keadaan yang tidak ideal

5. Ketidak teraturan menjadi hal lumrah

6. Motto Kota Serang Madani, hanya sebagai "Lips Service" semata

7. Rendahnya kesadaran diri (self consiusnes) dari masyarakat Kota Serang dalam mematuhi peraturanperaturan yang telah ditetapkan oleh pemerintah kota Serang.

Implementasi sebuah program, motto atau lainnya dikatakan berhasil apabila tujuan dari Program, motto atau lainnya memiliki dampak yang jelas terlihat.

Bila diperhatikan dari fenomena yang muncul dan beberapa hal penting diatas, maka
Motto Kota Serang Madani tersebut belum terimplementasi dengan baik. Karena apa yang diharapkan dari Motto tersebut tidak terwujud dengan baik dikehidupan seharihari.

\section{KESIMPULAN}

Motto merupakan sebuah penyemangat, motivator dalam menjalani sebuah kehidupan. Untuk sebuah kota, motto merupakan target dan tujuan dari diselenggarakannya pemerintahan kota. Maka dari itu, motto tersebut harus tersosialisai dengan baik ke setiap lapisan masyarakat.

\section{DAFTAR PUSTAKA}

Lorens Bagus, 1992. "Edmud Husserl, kembali pada benda-benda itu Sendiri", Para Filosof Penentu Gerak Zaman. Yogyakarta : Kanisius.

Al Fatih, Andy, 2010. Implementasi Kebijakan dan Pemberdayaan Masyarakat. Bandung: Unpad Press.

Lathief, Supaat I, 2010. Psikologi Fenomenologi Eksistensialisme. Lamongan: Pustaka Pujangga.

\section{Sumber Lain}

Selayang Pandang Kota Serang .www.dprdserangkota.go.id (diunduh pada tanggal 18 September 2017) 